\title{
Effect of Soil Compaction on Growth, Yield and Quality of Sugarcane (Saccharum Officinarum L.) Crop and It is Management: A Review
}

\author{
Dula Geneti \\ Ethiopian Institute of Agricultural Research, Jimma Agricultural Research Center, \\ P.O. Box 192, Jimma, Ethiopia
}

\begin{abstract}
Sugarcane is a tall growing monocotyledonous crop plant that is cultivated in the tropical and subtropical regions of the world primarily for its ability to store high concentrations of sucrose, or sugar, in the internodes of the stem. Sugar is not the only product of the cane that is used in the production of various products. Both the pulp and the outer portions of the stalk can be utilized in the creation of woven furniture, cardboard and other paper products, and disposable eating utensils. In spite of the importance of the crop there are many factors which cause the decrease in sugarcane productivity such as climate change and declining in soil fertility as an impact of conventional soil management. The use of heavy machinery during planting, harvesting and transporting operations in fine textured soils has led to the concern that subsoil compaction may decline long term productivity. Hence this leads to affects soil physical fertility, particularly storage and supply of water and nutrients, through increasing soil bulk density, decreasing porosity, increasing soil strength, decreasing soil water infiltration, and water holding capacity, and all of these processes lead to changes in plant physiology of sugarcane that leads to effect sugarcane growth, decline sugar yield and quality. Among many other management options of soil compactness; Soil Water Potential, Soil characterization before cultivation of land, Soil Tillage, passages of machine across the field and crop rotation is the major one.
\end{abstract}

Keywords: Sugarcane, Yield, Quality and Soil Compaction

DOI: $10.7176 / \mathrm{JEES} / 11-5-02$

Publication date:May $31^{\text {st }} 2021$

\section{Introduction}

Sugarcane (Saccharum officinarum) belongs to the Andropogonae tribe of the family Graminae. The subtribe is Sachare and the genus is Saccharum. Most of the sugarcane which is grown today is hybrids of Saccharum officinarum (Malavolta, 1994). Most of the sugarcane which is grown today is hybrids of Saccharum officinarum. Sugarcane is one of the most important field crops in the tropics. Indeed, according to (FAO 2001), world production of sugarcane was estimated to be about 1900 million $t$, which was grown on approximately 27.2 million hectares. Brazil was the largest producer at 737 million t (FAOSTAT, 2014). In Ethiopia the area coverage of the crop is about 31,236.81 ha with annual production of 1,410,311.54 tonnes (CSA, 2017).

Sugarcane is an important agricultural commercial cash crop and also unique in the sense that a number of succeeding cane crops are raised from a single planting which is an integral component of sugarcane production system. Sugarcane is grown for its sucrose content and is mostly consumed as refined sugar or other processed products. Raw sugarcane can be squeezed or chewed to extract the juice, which is known as "caldo de cana" or "garapa" in Brazil, "chediraz" in northern India and "aseer asab" in Egypt. In some countries in which sugarcane is grown, it is bottled for local distribution or sold fresh from juice bars, cafes and restaurants.

Outside of commercial processing, artisanal processing of sugarcane occurs where sugarcane juice is boiled and cooled to make cakes of unrefined brown sugar, known as "jaggery", "gur" and "khandsari" in India; "rapadura" in Brazil; and "panela" in Colombia. In India it is estimated that 16.5 million tonnes (t) of sugar are produced compared with 10 million t of these traditional sweeteners (Kansal, 1998).

In spite of the importance of the crop there are many factors which cause the decrease in sugarcane productivity such as climate change and declining in soil fertility as an impact of conventional soil management. Over the last 38 years, the annual cane yield has ranged from 50 to $110 \mathrm{Mg} \mathrm{ha}^{-1}$. The use of heavy machinery during planting, harvesting and transporting operations in fine textured soils has led to the concern that subsoil compaction may decline long term productivity. Hadas (1994) reviewed the theoretical analysis and experimental data on soil compaction under high axel load. He stated that subsoil compaction occurred under specific conditions, namely; wet, homogenous, and deep soil under high contact pressure. Axel loads exceeding $90 \mathrm{kN} \mathrm{m}^{-3}$ increased subsoil compaction (Salire et al., 1994).

Subsoil compaction can cause serious root restriction (Tardieu, 1994; Westermann and Sojka, 1996; Håkansson et al., 1996) and the loss of both transmission and water storage pores. These changes result in lower water infiltration due to the loss of transmission pores and higher soil water caused by the loss of storage pores (Soane et al., 1982; Gupta et al., 1987; Hadas, 1994; Lipiec et al., 1998), that may consequently reduce nutrition 
uptake and crop yield (Hammel, 1994; Westermann and Sojka, 1996; Håkansson et al., 1996; Grath and Arvids son, 1997). Torres et al. (1990) reported a decrease in sugarcane rooting depth and crop yield as a result of subsoil compaction.

Different parameters and methods are used to characterize soil compatibility, such as dry bulk density, vane shear strength, pore size distribution, gas and water diffusion, and morphological analysis (Hadas, 1994). Micro morphological studies were extensively used to characterize soil deformation (Jager et al., 1983; Koppi et al., 1992). Jager et al. (1983) indicated that macro pores and meso pores were less frequent in plough pans as compared with other soil layers, whereas micro pores were more common. However, little information is available on the micro morphology of compacted subsoil layers, particularly under sugarcane cultivation. Therefore, this review was initiated to conduct systematic investigations by concentrating on different research conducted on effect of soil compaction for sugarcane productivity and quality in the long term with the objectives of 1 . To provide an overview of effect of soil compaction on growth and yield of sugarcane. 2. To summarize the cause and management option of soil compaction for sugarcane production and quality. 3. To identifying future research areas to solve production problems with in adequate knowledge of soil compaction.

\section{Discussion}

\subsection{Origin and Domestication of Sugarcane}

The origins of S. officinarum are intimately associated with the activities of humans, as S. officinarum is a purely cultivated or garden species which is not found in the wild (Sreenivasan et al., 1987). The centre of origin of S. officinarum is thought to be in the Indonesia/New Guinea area (Daniels and Roach, 1987), where it has been grown as a garden crop since 8000 B.C. (Fauconnier, 1993). It has been proposed that S. officinarum evolved from the selection of sweet forms of S. robustum. The canes may have previously been used for house building, fencing and archery (Daniels and Roach, 1987) and may have been selected with the aid of animals such as pigs or rats that would have a preference for sweeter individual plants (Daniels and Roach, 1987). Its cultivation spread along the human migration routes to South East Asia, India and the Pacific, hybridizing with wild canes. It reached the Mediterranean around 500 B.C. (Fauconnier, 1993). From there it spread to Morocco, Egypt, the Syrian Arab Republic, Crete, Greece and Sicily, the main producers until the $15^{\text {th }}$ century, followed by introduction to West Africa and subsequently Central and South America and the West Indies (Fauconnier, 1993). It is thought to have reached Australia in 1788 on the First Fleet, but did not become established until after it was reintroduced in 1817 from Tahiti (Bull and Glasziou, 1979).

S. spontaneum is believed to have evolved in southern Asia (Daniels and Roach, 1987). It accumulates little sucrose content and has thinner stalks and higher fibre content than S. officinarum (Jackson, 2005). Saccharum spontaneum is an adaptable species and grows in a wide range of habitats and at various altitudes in the tropics through to temperate regions, from latitude $8^{\circ} \mathrm{S}$ to $40^{\circ} \mathrm{N}$ extending across three geographical zones. These are: 1) the east zone which is Burma, China, Japan, Malaysia, the Philippines, Chinese Taipei, Thailand Viet Nam and the South Pacific Islands; 2) the central zone, which includes Afghanistan, Bangladesh, India, the Islamic Republic of Iran, Nepal, Pakistan, Sri Lanka and the Middle East; and 3) the west zone which includes Egypt, Kenya, Sudan, the United Republic of Tanzania, Uganda and other countries in the Mediterranean (Panje and Babu, 1960; Tai and Miller, 2001).

Commercial sugarcane hybrid cultivars have arisen through intensive selective breeding of species within the Saccharum genus, primarily involving crosses between S. officinarum and S. spontaneum. Saccharum officinarum accumulates very high levels of sucrose in the stem but is highly susceptible to diseases (Cox, Hogarth and Smith, 2000; Lakshmann et al., 2005), whereas S. spontaneum accumulates little sucrose, has thinner stalks and higher fibre content but is a highly polymorphic species with resistance or tolerance to many pests and diseases (Bull and Glasziou, 1979; Jackson, 2005).

\subsection{Current Status of Sugarcane in Ethiopia}

Commercial sugarcane production has a history of six decades, sugarcane had been cultivated in Ethiopia since century. According to the report by central statistics agency (CSA) currently sugarcane is produced in about $31,236.81$ ha with $1,565,060.00$ holdings in different parts of the country (CSA, 2017). But the production is not usually used for industrial purposes. It is noticeably used for making confectioneries, household consumption (chewing), selling for immediate cash, and feeding livestock. In some areas, sugarcane is used to prepare local beverage called "Karibo" mainly preferred by Muslim communities, while in others the leaves are used for thatching and as firewood (Esayas, 2014). However, the potential of this sector is not well explored and has not been given due consideration. Furthermore no exploration and germplasm collection have been done to represent and preserve local landraces.

Sugarcane plays a significant role in the Ethiopian socio-economy. Sugar and its byproduct are used for local consumption and export. The industry created job opportunity for a large number of people. Today in the country sugar consumption outstrips its production. The per capita sugar consumption in Ethiopia is very low (5- 
$6 \mathrm{~kg}$ ) which is even below the African standard $(15 \mathrm{~kg})$ while the world average per capita consumption is $21 \mathrm{~kg}$ in 2016. The commercial sugarcane sector in Ethiopia commenced since 1951. Sugar Corporation of Ethiopia currently administers six sugar factories, namely, Wonji-Shoa, Metahara, Finchaa, Tendaho, Arjo-dedessa, and Kessem, and nine sugar development projects at Kuraz, Tana Beles, and Welkayit. Sugarcane plantations are expanding with current area coverage of 98,986 hectares and production of 400,000 tons of sugar and 25,388 $\mathrm{m}^{3}$ of ethanol per annum.

In spite of the great importance of Ethiopian sugarcane, analysis of soil compactness to increase sugarcane production and quality across the country is lacking. No efforts have been made so far to asses and document the effect of soil compactness. Furthermore, study of the variation and assessment of extent and geographical pattern of distribution of soil compactness is lacking in Ethiopia when compare with other parts of the world.

\subsection{Causes and Effect of soil compaction}

a. Causes of soil compaction

The use of heavy machinery during planting, harvesting and transporting operations in fine textured soils has led to the concern that subsoil compaction may decline long term productivity. Soil compaction caused by agricultural traffic is commonly accepted as one of the causes of reduced crop productivity. This was attributed to increased spatial variability in crop stand, water, nutrient and root distribution (Hadas et al., 1986). Soil compaction due to machinery traffic causes substantial losses at the farm level but the extent of it depends on the tractor size used, machinery use intensity, weather conditions, and the type of crop grown (Lavoie et al., 1991). Harris and Pearce (1990) presented a design for a large capacity, high flotation haulout bin that would be compatible for cane harvesting areas throughout Australia. No assessment of a reduction in soil compaction compared with conventional equipment was made.

Soil water content is the most important factor influencing soil compaction processes (Soane and Van Ouwerkerk, 1994). In sugarcane harvesting systems, harvesters or transshipment machines with total weight ranging from 20 to $30 \mathrm{t}$ are commonly used, and their traffic occurs during several crop cycles at varying conditions of water content in soil with high compaction potential, causing physical and structural degradation of the soil (Cavalieri et al., 2011). Root penetration resistance (RPR) and Bulk density (BD) have been used to define the levels of soil compaction so that corrective measures could be implemented. Sene et al., (1985) recorded values between 6.0 and 7.0 $\mathrm{MPa}$ as critical for the growing of plant roots in sandy soils, and a value of $2.5 \mathrm{MPa}$ for clayey soils. Regarding bulk density, the critical values are $1.65 \mathrm{Mg}$ (sandy soils) and $1.45 \mathrm{Mg}$ (clayey soils) (Araujo et al., 2004).

On the other hand, when we consider manual harvesting system, the burning of straw aims to facilitate the process, however, it is a harmful practice to the maintenance of organic matter (OM) levels, because it reduces the supply of total organic matter and favors its mineralization (Ceddia et al., 1999). The remaining straw deposited on the soil under this type of system is of $3.0 \mathrm{Mg} / \mathrm{ha} / \mathrm{year}$, on the average estimate (Souza et al., 2005), so soil coverage will be lower and the loss of soil and nutrients will be greater, in addition to having a negative influence on the physical quality of soils (Garbiate et al., 2011).

Torres et al (1990) also compared the effect of row and inter-row compaction under wet harvest conditions on soil properties and subsequent ratoon yield. Passage of machinery resulted in an increase in bulk density and soil strength. Correspondingly porosity and infiltration rate decreased. However, direct damage to the stool by equipment was thought to be the largest cause of yield decline.

b. Effect of soil compaction on Growth of Sugarcane

For sugarcane, adverse soil properties associated with compacted soils negatively affect root growth rates (Torres and Rodrigues, 1995). The physiological cost of recovering the functions of fine roots may be as high as $70 \%$ of the accessible carbon flow (Vogt et al., 1996). Kozlowski (1999) found that the increased carbon flow due to soil compaction leads to an overall decrease in photosynthesis. This is a result of reduced foliage surface, which is an outcome of reduced water intake caused by changes in the soil structure and moisture conditions (Arvidsson \& Jokela, 1995). Therefore, a plant might not have enough energy to reconstruct its root system, and the growth of roots as well as the above-ground parts stagnate or even die. Reduced foliage surface is a reaction to a water deficit in the leaves, which is brought about by soil compaction and may lead to the closing of pores and further loss of photosynthesis (Masle \& Passioura, 1987).

Often, extreme soil compaction leads to reduced absorption of mineral nutrients by the roots, especially nitrogen, phosphorus and potassium. Nutrient uptake is reduced as a result of the loss of minerals from soil, reduction of root access to nutrients and decreased root capacity for nutrient intake (Kozlowski \& Pallardy, 1997). A reduction of nutrient uptake caused by soil compaction in the upper as well as deeper soil layers (Kozlowski, 1999) might be the reason for different reactions to the compaction among species, as some have higher nutrient demands than others.

Potassium deficiency results in depressed growth, thin stalks and yellowing of the older leaves with chlorotic spots and ultimately death of the leaf (Bakker, 1999). Potassium may also play a role in the ability of 
sugarcane to withstand dry conditions (Wood and Schroeder, 2004). Since absorption of potassium is declined by effect of soil compactness the tolerance sugarcane plants are become susceptible to peculiar adverse environmental effect.

Magnesium is important for photosynthesis, being required for chlorophyll function, and is responsible for the green colour in the leaves (it absorbs the blue and red light spectrum). Deficiencies result in leaf chlorosis and stalks of reduced diameter with internal browning (Bakker, 1999).

c. Effect of soil compaction on yield and Quality of Sugarcane

Soil compaction is the reduction in the volume of the pores due to an external force. In such conditions, the distribution and the size of the pores are altered, reducing the permeability and hydraulic conductivity. As a result of this, bad ventilation of soil, increase of bulk density and yield reduction is resulted. The yield reduction occurs due to limitation of root growth and so declining their efficiency to absorb nutrients.

It has been estimated that a crop of 74 tonnes of cane per ha removes $107 \mathrm{~kg}$ nitrogen, $60 \mathrm{~kg}$ phosphorus oxide and $300 \mathrm{~kg}$ potassium oxide per ha (Purseglove, 1972). The sugarcane plant requires nitrogen for optimum development for yield and sugar content of the canes. Symptoms of nitrogen deficiency are thin, stunted stalks; yellowing leaves with necrosis at the edge and tips; and reduced root mass (Calcino, Kingston and Haysom, 2000). However, excess nitrogen can prolong the crop maturation, resulting in a plant with an excessive leafy canopy, which in turn can make the plant more susceptible to leaf diseases and attack by pests (Bakker, 1999). It can also cause excess growth with little storage of sucrose (Irvine, 2004). This clearly showed that the effect of soil compactness in quality of sugarcane.

Phosphorus is required for optimum growth. Deficiencies may manifest as plants with short, thin stalks and stools with a low number of primary stalks, a poorly developed root system and sometimes leaves that are greenblue in colour. Conversely, an excess of phosphorus can lead to a deficiency of other trace elements such as zinc and iron, thus reducing sugar yields (Bakker, 1999). Potassium is required for many physiological processes. It helps to promote the formation and translocation of sugars, and thus may improve the extraction and purity of the cane juice. Supplementing sugarcane plants that are exposed to excessive nitrogen with potassium can alleviate the symptoms of over-supply of nitrogen.

Calcium is an important element for plant growth and also a regulator of soil acidity. A deficiency in calcium results in leaf chlorosis and reduced stem diameter. Increasing soil acidity, which can be ameliorated by lime application, can result in an increased fixation of phosphorus, aluminum, iron, manganese and nickel, which may lead to toxicity (Bakker, 1999). Thus, these will be contributed reducing sugar yields and quality.

Generally soil compaction is the reduction in the volume of the pores due to an external force. In such conditions, the distribution and the size of the pores are altered, reducing the permeability and hydraulic conductivity. As a result of this, bad ventilation of soil, increase of bulk density and yield reduction is resulted. The yield reduction occurs due to limitation of root growth and so declining their efficiency to absorb nutrients. Table 1. Yield response and proportion of deformed roots of sugarcane in clay soil

\begin{tabular}{lcc}
\hline Location of compacted layer $(\mathrm{cm})$ & Decrease of yield $(\%)$ & Deformed roots $(\%)$ \\
\hline Non-compacted & $100 \%=32.54 \mathrm{Mg} / \mathrm{ha}$ & 2.1 \\
$<28$ & $10-13$ & 5.6 \\
$<22$ & $21-25$ & 13.4 \\
$6-10$ and below 28 & $29-32$ & 18.8 \\
$0-30$ (compacted after sowing) & $55-59$ & 53.2 \\
\hline
\end{tabular}

Source; (Birkás M. and Gyuricza C, 2001)

\subsection{Management options of Soil Compaction in Sugarcane production}

A. Soil Water Potential

At all compaction levels, the penetration resistance increases with decreasing soil water potential (Lipiec et al., 2002). In other words, increasing soil moisture content causes a reduction in the load support capacity of the soil, thus decreasing the permissible ground pressure (Medvedev and Cybulko, 1995). Knowing the changes in soil compaction with changes in water content helps to schedule farm trafficking and cultivation operations at the appropriate moisture content (Ohu et al., 1989). Soil deformation increases with moisture content and the number of passes and timing of tillage in relation to soil water moisture content and soil texture (Hakansson and Lipiec, 2000). For any compaction energy level it is thus necessary to define the moisture content of the soil corresponding to the liquid, plastic and solid limits (Quiroga et al., 1999). Soil water infiltration rate also can be used to monitor soil compaction status, especially of the topsoil. Water infiltrates un-compacted soils that have well-aggregated soil particles much faster than massive, structure-less soils (Hamza and Anderson, 2002a, 2003). B. Soil characterization before cultivation of land

Batey, (1990), reported that the effects of soil compaction on crops and soil properties are complex and since the state of compactness is an important soil structural attribute, there is a need to find a parameter for its characterization, such as relative bulk density, that gives directly comparable values for all soils (Hakansson and 
Lipiec, 2000). Since soil bulk density is the mass of dry soil per unit volume, then the relationship between soil compaction and its capacity to store and transport water or air is obvious. For this reason the dry soil bulk density is the most frequently used parameter to characterize the state of soil compactness (Panayiotopoulos et al., 1994). Hence, before cultivation of land soil characterization is must by using afro mentioned parameters to identify weather it is compactness or not.

C. Soil Tillage system

The current management techniques of sugarcane cultivation are based on vigorous soil tillage during preparation and planting, which together with to the harvest system used (manual or mechanized), cause alterations in the physicochemical properties and levels of organic matter (OM) of the soil (Vasconcelos et al., 2010). The following main changes have been observed in the physical properties of soils: reduction in macro porosity, change in aggregate size, reduction in water infiltration rate, increase in bulk density (BD), and increase in root penetration resistance (Rpr) (Camargo; Marques Júnior; Pereira, 2010), which may eventually cause decrease in crop yield. Therefore, soil depending harvesting system choice of appropriate tillage system is paramount important to avoid soil compaction.

D. Passage of machinery

In sugarcane harvesting systems, harvesters or transshipment machines with total weight ranging from 20 to $30 \mathrm{t}$ are commonly used, and their traffic occurs during several crop cycles at varying conditions of water content in soil with high compaction potential, causing physical and structural degradation of the soil (Cavalieri et al., 2011).

Torres et al (1990) also compared the effect of row and inter-row compaction under wet harvest conditions on soil properties and subsequent ratoon yield. Passage of machinery resulted in an increase in bulk density and soil strength. Therefore, making passage of machinery across the farm is paramount important to reduce the effect of soil compactness come-up with heavy machinery.

E. Crop rotation

The effect of roots on soil structure depends on the species grown, soil constitution and environmental factors (Monroe and Kladivko, 1987). The effect is also influenced by soil micro-flora associated with plant roots (Tisdall, 1991). Plants grown in compacted soil have shown a smaller number of lateral roots with less dry matter than plants grown under controlled conditions at both low and high soil water contents (Panayiotopoulos et al., 1994). Roots grown in more compact soil had smaller ratios of fresh to dry mass. Soil compaction can have adverse effects upon plants growing in the soil by: increasing the mechanical impedance to the growth of roots, altering the extent and configuration of the pore space (Tardieu, 1994).

Roots of different crop species, as well as of cultivars within species, differ considerably in their ability to penetrate through hard soil layers (Singh and Sainju, 1998). Their response is related to the ability of the root system to overcome the soil strength limitations of compacted soil (Kirkegaard et al., 1992). Plant species that have the ability to penetrate soils with high strength usually possess a deep tap root system. Incorporating such species in the rotation is desirable to minimize the risks of subsoil compaction (Ishaq et al., 2001b). If there is enough topsoil for root growth, roots will concentrate themselves there and increases in density of the subsoil may not result in significant decreases in yield. Sugarcane continuous cropping, together with inadequate management practices, as intense traffic of machinery and the absence of crop rotation, can result in soil degradation and reduce productivity (Masilaca et al., 1986).

\section{Conclusion}

Now a day's sugarcane production has many advantages due to its products and byproducts. Products such as, the sugar juice is used for making sugar, and several byproducts are produced from crushing sugarcane at the sugar mill. This includes alcohol, molasses, bagasses, and syrup. In spite of the importance of the crop there are many factors which cause the decrease in sugarcane productivity such as climate change and declining in soil fertility as an impact of conventional soil management. Among many conventional soil management soil compaction adversely affects soil physical fertility, particularly storage and supply of water and nutrients, through increasing soil bulk density, decreasing porosity, increasing soil strength, decreasing soil water infiltration, and water holding capacity, and all of these processes lead to changes in plant physiology of sugarcane that leads to effect sugarcane growth, decline sugar yield and quality. The current management techniques of sugarcane cultivation should be based on vigorous soil tillage during preparation and planting, which together with to the harvest system used (manual or mechanized), cause alterations in the physicochemical properties and levels of organic matter (OM) of the soil. Among many management options of soil compactness Soil Water Potential, Soil characterization before cultivation of land, Soil Tillage, passages of machine across the field and crop rotation is the major one.

\section{Recommendations and future prospective}

$\checkmark \quad$ Effect of soil compaction on growth, yield and production of sugarcane should be considered as measure. 
$\checkmark \quad$ Sugarcane harvesting, planting and fertilizer application in the field at wet time can cause soil compaction due to mechanized method, so as much as possible doing all this works should be practiced at fully dry time, if it's impossible manual work is better.

$\checkmark \quad$ Soil compaction also causes disorder in plant physiological processes by reducing amount of water in the soil, limiting movement of nutrients in the soil, closing soil pore spaces, diminishing water and soil air balance, reduction in aeration and also limits growth and water uptake of roots, so as much as possible sub soiling, early earthling up, continuous following up the field after doing works mechanically.

$\checkmark$ Accordingly it is important to till the soil at the right soil moisture if compaction is to be minimized and measuring the bulk density of the soil before using machines in the field should be done to minimize the effects of soil compaction on soil and to have better production of sugarcane in the future.

$\checkmark \quad$ Giving awareness and teaching society about the impact of soil compaction on the growth, yield and quality of sugarcane will be paramount importance

$\checkmark$ Assessment of soil compactness for Ethiopian like countries is paramount important, because of to know current yield also occurred by this problem and to design strategies for the problem that leads to increase overall economy of the country

\section{Reference}

Araujo, M. A.; Tormena, C. A.; Inoue, T. T.; Costa, A. C. S. 2004. Efeitos da escarificação na qualidade física de um Latossolo Vermelho distroférrico após trezes anos de semeadura direta. Revista Brasileira de Ciência do Solo, v. 28, n. 3, p. 459-504.

Arvidsson, J. \& Jokela, W.E. (1995). A lysimeter study of soil compaction on wheat during

Bandalan, E.P., V.M. Salokhe, C.P. Gupta and T. Niyamapa, 1999. Performance of an oscillating subsoiler in breaking a hardpan. J. Terramechanics, 36: 117-125.

Barzegar, A.R., M.A. Asoodar and M. Ansari, 2000. Effectiveness of sugarcane residues incorporation at different water contents and the Proctor compaction loads in reducing soil compatibility. Soil Tillage Res., 57: 167-172.

Batey, T., 1990. Control of compaction on the farm. A personal view. Soil Technol. 3, 225-229.

Bennie, A T P and Burger, R. du T. (1979).Soil compaction underirrigation in the Vaalharts Irrigation Scheme. Dept of Soil Science, Report No 79/2. ofs.

Birkás M. and Gyuricza C., 2001. INCO-Copernicus concerted action on 'Expertiences with the impact of subsoil compaction on soil nutrition, crop growth and environment and ways to

Bramley, R.G.V., N. Ellis, R.O. Nable and A.L. Garside, 1996. Changes in soil chemical properties under longterm sugar cane monoculture and their possible role in sugar yield decline. Aust.J.SoilRes.,34:967-984.

Braunack, M and McGarry, D. 2006. Traffic control and tillage strategies for harvesting and planting of sugarcane (Saccharumofficinarum) in Australia.Soil and Tillage Research 89 (1): 86-102.

Braunack, M, Wood, A, Dick, R and Gilmour, J. 1993. The extent of soil compaction in sugarcane soils and a technique to minimize it.Sugar cane 5: 12-18.

Camargo, L. A.; Marques Júnior, J.; Pereira, G. T 2010. Spatial variability of physical attributes of alfisol under different hillslope curvatures. Revista Brasileira de Ciência do Solo, v. 34, n. 3, p. 617-630.

Cavalieri, K. M. V.; Carvalho, L. A.; Silva, A. P.; Libardi, P. L.; Tormena, C. A 2011. Qualidade física de três solos sob colheita mecanizada de cana-de-açúcar. Revista Brasileira de Ciência do Solo, v. 35, n. 5, p. 1541-1549.

Ceddia, M. B.; Anjos, L. H. C.; Lima, E.; Ravelli Neto, A.; Silva, L. A 1999. Sistemas de colheita da cana-deaçúcar e alterações nas propriedades físicas de um solo podzólico amarelo no Estado do Espírito Santo. Pesquisa Agropecuária Brasileira, v. 34, n. 8, p. 1467-1473.

Central Statistics Agency (CSA), "Agricultural sample survey: Area and production of major crops: private peasant holdings," Statistical Bulletin, Addis Ababa, Ethiopia, 2017.View at: Google Scholar

Cerri, C. C.; Galdos, M. V.; Maia, S. M. F.; Bernoux, M.; Feigl, B. J.; Powlson, D.; Cerri, C. E. P 2011. Effect of sugarcane harvesting systems on soil carbon stocks in Brazil: an examination of existing data. European Journal of Soil Science, v. 62, n. 1, p. 23-28.

Cerri, D. G. P.; Magalhães, P. S. G. Correlation of physical and chemical attributes of soil with sugarcane yield. Pesquisa Agropecuária Brasileira, v. 47, n. 4, p. 613-620.2012

Chapman, L.S. 1996. Australian sugar industry by-products recycle plant nutrients. In : Downstream effects of land use (Ed. Hunter, H.M., Eyles, A.G. and Rayment, G.E.). Queensland Department of National Resources, Queensland, Australia.

Coale, F.J., Sanchez, C.A., Izuno, F.T. and Bottcher, A.B. 1993.Nutrient accumulation and removal by sugarcane grown on Everglades Histosols.Agronomy Journal 85: 310-315.

Cochrane, H.R., Aylmore, L.A.G., 1994. The effects of plant roots on soil structure. In: Proceedings of 3rd Triennial Conference "Soils 94". pp. 207-212. early tillering. II. Concentration of cell constituents. New 
Phytol 115:37-41.

CSA, 2016/2017. Report on area and production of crops by Central Statistics Agency agricultural sample survey in 2017/2016, Addis Ababa, Ethiopia.

FAO. 2001. Faostat Agriculture Data. Food and Agriculture Organization of the United Nations, Rome.

FAOSTAT (2014), FAO Statistics online database, "Production / Crops, - sugarcane, Year 2014", Food and Agriculture Organization of the United Nations, http://faostat3.fao.org/home/E (accessed 10 February 2016)

Forest Research 14:596-619.

Garbiate, M. V.; Vitorino, A. C. T.; Tomasini, B. A.; Bergamin, A. C.; Panachuki, E 2011. Erosão em entre sulcos em área cultivada com cana crua e queimada sob colheita manual e mecanizada. Revista Brasileira de Ciência do Solo, v. 35, n. 6, p. 2145-2155.

Georges, J, Mohammed, M and Harvey, W. 1985. Effects on soil water content and compactive effort on soil compaction and sugar cane regrowth. Proceedings of the 32 West Indies Sugar Technologists Conference, 23: $635-640$.

Ghildyal BP and Satyanarayana T (1965). Effect of compaction on the physical properties of four different soils in India.Journal of the Indian Society of Soil Science 13 149-55.

Greenland DJ (1977). Soil damage by intensive arable cultivation: temporary or permanent? Philosophical Transactions of the Royal Society B: Biological Sciences 281 193-208.

Ha kansson, I., Lipiec, J., 2000. A review of the usefulness of relative bulk density values in studies of soil structure and compaction. Soil Tillage Res. 53, 71-85.

Hadas A., Wolf D., and Rawitz E., 1986. Prediction of draft requirement-soil compaction relations in tilling moist soils. Soil Till. Res., 8, 51-64.

Hamza, M.A., Anderson, W.K., 2002a. Improving soil fertility and crop yield on a clay soil in Western Australia Aust. J. Agric. Res. 53, 615-620.

Harris, H 13 and Pearce, F (1990).The analysis and design of infield haulout bins forthe Australian cane industry. Agric. Engng. Conf., Inst. Engrs., Aust. Natl. Conf. Publ. No. 90/13 p 10-14.

Hartemink, A.E., 1998. Soil chemical and physical properties asindicators of sustainable land management under sugar cane inPapua New Guinea.Geoderma85, 283-306.

Ishaq, M., Ibrahim, M., Hassan, A., Saeed, M., Lal, R., 2001b. Subsoil compaction effects on crops in Punjab, Pakistan: II. Root growth and nutrient uptake of wheat and sorghum. Soil Tillage Res. 60, 153-161.

Jackson, P, Braunack, M, Foreman, J and Peatey, T. 2000. Genetic variation in sugarcane for ratooning after harvester damage in wet soil.Euphytica111 (1): 1-8.

Kirkegaard, J.A., Troedson, R.J., So, H.B., Kushwaha, B.L., 1992. The effect of compaction on the growth of pigeonpea on clay soils. II. Mechanisms of crop response and season effects on an oxisol in a humid coastal environment. Soil Tillage Res. 24, 129-147.

Kozlowski, T.T. \& Pallardy, S.G. (1997). Physiology of Woody Plants, 2nd edition. Academic

Kozlowski, T.T. (1999). Soil compaction and growth of woody plants. Scandinavian Journal of

Krejcir J (1990) Obecna' produkce rostlinna'. Skriptum, MZLU, Brno 133s.

Lavoie G., Gunjal K., and Raghavan G.S.V., 1991. Soil compaction, machinery selection and optimum crop planning. Transactions of the ASAE, 34, 2-8.

Lipiec, J., Ferrero, A., Giovanetti, V., Nosalewicz, A., Turski, M., 2002. Response of structure to simulated trampling of woodland soil. Adv. Geoecol. 35, 133-140.

Malavolta, E. 1994. Nutrient and fertilizer management in sugarcane.International Potash Institute Bulletin No. 14. International Potash Institute, Basel, Switzerland.

Martins Filho, M. V.; Liccioti, T. T.; Pereira, G. T.; Marques Júnior, J.; Sanchez, R. B. 2009. Perdas de solo e nutrientes por erosão num Argissolo com resíduos vegetais de cana-de-açúcar. Engenharia Agrícola, v. 29, n. 1, p. 8-18.

Masilaca, A.S., R.A. Prasad and K.J. Morrison, 1986. The impact of sugar-cane cultivation on three oxisols from Vanu Levu Fiji. Trop. Agric., 63: 325-330.

Masle, J. \& Passioura, J.B. (1987). The effect of soil strength on the growth of young wheat.

Mason, E.G., Cullen, A.W.J., Rijkse, W.C., 1988. Growth of two Pinus radiata stock types on ripped and ripped/bedded plots at Karioi forest. N. Zeal. J. Forestry Sci. 18, 287-296.

Medvedev, V.V., Cybulko,W.G., 1995. Soil criteria for assessing the maximum permissible ground pressure of agricultural vehicles on Chernozem soils. Soil Tillage Res. 36, 153-164.

Meyer, J, Van Antwerpen, R and Meyer, E. 1996.A review of soil degradation and management research under intensive sugarcane cropping.Proceedings of the South African Sugar Technologists' Association, 70: 22-28. Durban, South Africa.

Meyer, J. 1996b. Soil management research for sustainable ratoon cane production in the South African sugar industry.Proceedings of the XXII Congress of the International Society of Sugar Cane Technologists, 14-21. Carthagena, Colombia. 
Monroe, C.D., Kladivko, E.J., 1987. Aggregate stability of a silt loam as affected by roots of maize, soybean and wheat. Commun. Soil Sci. Plant Anal. 18, 1077-1087.

Monteith, N H and Banath, C L (1965). The effect of soil strength of sugarcane rootgrowth. Tropical Agric., 42:293-296

Ohu J.O. and Folorunso O.A., 1989. The effect of machinery traffic on the physical properties of a sandy loam soil and on the yield of sorghum in North-eastern Nigeria. Soil Till. Res., 13, 399-405.on soil microbial activity and N losses. Commun. Soil Sci Plant Anal 23:1321-1331.

Panayiotopoulos, K.P., Papadopoulou, C.P., Hatjiioannidou, A., 1994. Compaction and penetration resistance of an Alfisol and Entisol and their influence on root growth of maize seedlings. Soil Tillage Res. 31, 323-337.

Pankhurst, C.E., R.C. Magarey, G.R. Stirling, B.L. Blair, M.J. Bell and A.L. Garside, 2003. Management practices to improve soil health and reduce the effects of detrimental soil biota associated with yield decline of sugarcane in Queensland, Australia. Soil Tillage Res., 72: 125-137.

Patel MS and Singh NT (1981). Changes in bulk density and water intake rate of a coarse textured soil in relation to different levels of compaction. Journal of the Indian Society of Soil Science 29 110-2.

Pinto, A and Bellinaso, I. 2000. Chopped sugarcane harvesting: Equipment traffic studies and effects on yields. Proceedings of the International Society of Sugar Cane Technologists Agricultural Engineering Workshop, 75-81. Malelane, South Africa. plants. Australian Journal of Plant Physiology 14:643-656.

Pranagal J (2004) Wpływ systemu uprawy na zawartos'c' we, gla organicznego w glebie. Annales UMCS Sec. E 59(1):1-10.

Prax A, et al. (1995) Pudoznalstvi'. Skriptum, MZLU, Brno, p 61sPress, San Diego. prevent subsoil compaction' Final report of Hungarian group (manuscript).

Prove, B G, Truong, P N and Evans, D (1986). Strategies for controlling canelanderosion in the wet tropical coast of Queensland. Proc. Aust. Soc. Sugar Cane Technol., 8:77-84.

Quiroga, A.R., Buschiazzo, D.E., Peinemann, N., 1999. Soil compaction is related to management practices in the semi-arid Argentine pampas. Soil Tillage Res. 52, 21-28.

Radford BJ, Bridge BJ, Davis RJ, McGarry D, Pillai UP, Rickman JF, Walsh PA and Yule DF (2000). Changes in the properties of Vertisol and responses of wheat after compaction with harvester traffic. Soil and Tillage Research 54 155-70.

Schultz, N.; Lima, E.; Pereira, M. G.; Zonta, E. 2010. Efeito residual da adubação na cana-planta e da adubação nitrogenada e potássica na cana-soca colhidas com e sem a queima da palhada. Revista Brasileira de Ciência do Solo, v. 34, n. 3, p. 811-820.

Segato, S. V.; Mattiuz, C. F. M.; Mozambani, A. E. 2006. Aspectos fenológicos da cana-de-açúcar. In: SEGATO, S. V. et al. Atualização em produção de cana-de-açúcar. Piracicaba: Livroceres,. p. 19-36.

Sene, M.; Vepraskas, M. J.; Naderman, G. C.; Denton, H. P. 1985. Relationsships of soil texture and structure to corn yield response to subsoiling. Society Soil Science Society of America Journal,v.49,n.2, p. 422-427.

Shafi, MahommadCh, Shah, M L, Mahmmod, T, Afghan, S and Shah, S H (1990).Cane yield and quality of sugar cane as influenced by different planting pattern.Pakistan Sugar 3., IV(2):3-4.

Singh, B.P., Sainju, U.M., 1998. Soil physical and morphological properties and root growth. Hort. Sci. 33, 966971.

Soane, B.D., Van Ouwerkerk, C. (Eds.), 1994. Soil Compaction in Crop Production, Developments in Agricultural Engineering Series, vol. 11. Elsevier Science, Amsterdam, The Netherlands, pp. 662.

Souza, G. S.; Souza, Z. M.; Silva, R. B.; Araújo, F. S.; Barbosa, R. S. 2012. Compressibilidade do solo e sistema radicular da cana-de-açúcar em manejo com e sem controle de tráfego. Pesquisa agropecuária brasileira, v. 47, n. 4, p. 603-612.

Souza, H. A.; Marcelo, A. V.; Centurion, J. F. 2012. Carbono orgânico e agregação de um Latossolo Vermelho com colheita mecanizada de cana-de-açúcar. Revista Ciências Agronômicas, v. 43, n. 4, p. 658-663.

Souza, Z. M.; Prado, R. M.; Paixão, A. C. S.; Cesarin, L. G. 2005. Sistemas de colheita e manejo da palhada de cana-açúcar. Pesquisa Agropecuária Brasileira, v. 40, n. 3, p. 271-278. species. Plant Soil 187:159-219.

Sur HS, Prihar SS and Jalota SK (1980).Effect of rice-wheat and maize-wheat rotation on water transmission and wheat root development in a sandy loam soil of Punjab, India.Soil and Tillage Research 1 361-71.

T. Esayas, Exploration and Collection, Characterization, Genetic Diversity Analysis and Association of Traits for Yield and Yield Components of Sugarcane (Saccharumspp.) in Ethiopia [Master Thesis], Haramaya University, Dire Dawa, Ethiopia, 2014.

Tardieu, F., 1994. Growth and functioning of roots and of root systems subjected to soil compaction. Towards a system with multiple signalling. Soil Tillage Res. 30, 217-243.

Taylor NH and Pohlen IJ, (1962). Soil survey method. A new Zealand handbook for the field study of soils. NZ Soil Bur Bull 25, DSIR, New Zealand, 100.

Tisdall, J.M., 1991. Fungal hyphae and structural stability of soil. Aust. J. Soil Res. 29, 729-743.

Torbert, H.A. \& Wood, C.W. (1992). Effects of soil compaction and water-filled pore space. 
Torres, J and Rodrigues, L. 1995. Soil compaction management for sugarcane.Proceedings of the Congress of the International Society of Sugar Cane Technologists, 7-15. Carthagena, Colombia.

Torres, J S, Yang, S J and Villegas, F (1990).Soil compaction and sugarcane stooldamage due to semimechanised harvesting in the wet season. Proc. Int. Soc.Sugar Cane Technol., XX Vol. 2:992-999.

Van Antwerpen R and Meyer JH, (1996).Soil degradation under sugarcanecultivation in northern KwaZuluNatal.Proc S AfrSugTechnol Ass 70: 29-33.

Van Antwerpen, R, Meyer, J and Meyer, E. 2000.Soil compaction in the South African sugar industry-a review.Proceedings of the South African Sugar Technologists' Association, 74: 101-108. Durban, South Africa.

Vasconcelos, R. F. B.; Cantalice, J. R. B.; Oliveira, V. S.; Costa, Y. D. J.; Cavalcante, D. M. 2010. Estabilidade de agregados de um Latossolo Amarelo distrocoeso de Tabuleiros Costeiro sob diferentes aportes de resíduos orgânicos da cana-de-açúcar. Revista Brasileira de Ciência do Solo, v. 34, n. 2, p. 309-316.

Vogt, K.A.; Vogt, D.J.; Palmiotto, P.A.; Boon, P.; O’hara, J. \& Asbjotnsen, H. (1996). Review of root dynamics in forest ecosystems grouped by climate, climatic forest type.

Weber, R., Hrynczuk, B., Biskupski, A., Wlodek, S., 2000. Variability of compaction, density and moisture of soil as depending on the tillage technique. Inzynieria Rolnicza 6, 319-325.

Wood, R.A. 1990. The roles of nitrogen, phosphorus and potassium in the production of sugarcane in South Africa.Fertilizer Research 26: 87-98.

Yadav, R. L., \&Shukla, S. K. (2008). Sugarcane production technology for hgher productivity. In: Proceedings of National Seminar on varietal planning for improving productivity and sugar recovery in Sugarcane held at G.B.P.U.A. \& T. Pantnagar, 14-15 Feb. 2008, pp. 207-209. 